\title{
Drying and storage of Melanoxylon brauna Schott. seeds
}

\author{
J. M. Freire ${ }^{a *}$ (D), J. R. C. Rouws ${ }^{a}$ (D), T. B. Breier ${ }^{b}$ (D) and G. M. Ataide ${ }^{c}$ \\ ${ }^{a}$ Empresa Brasileira de Pesquisa Agropecuária - Embrapa Agrobiologia, Rodovia BR 465, Km 07, CEP 23891-000, \\ Seropédica, RJ, Brasil \\ 'Laboratório de Biologia Reprodutiva e Conservação de Espécies Arbóreas - LACON, Departamento de Silvicultura, \\ Instituto de Florestas, Universidade Federal Rural do Rio de Janeiro - UFRRJ, Rodovia BR 465, Km 07, CEP 23897-000, \\ Seropédica, RJ, Brasil \\ 'Departamento de Ciências Agrárias, Universidade Federal de São João Del-Rei - UFSJ, Campus Sete Lagoas, \\ Rodovia MG-424, Km 47, CEP 35700-000, Sete Lagoas, MG, Brasil \\ *e-mail: juliana.muller@embrapa.br
}

Received: December 27, 2019 - Accepted: April 3, 2020 - Distributed: May 31, 2021

(With 4 figures)

\begin{abstract}
The objective of this work was to evaluate the sensitivity of Melanoxylon brauna Schott. tree legume seeds to desiccation and storage. In the drying experiment, the Melanoxylon brauna seeds were submitted to two drying conditions: a forced air circulation chamber $\left(40.18{ }^{\circ} \mathrm{C} \pm 0.13\right.$ and $\left.28.48 \% \pm 3.95 \mathrm{RH}\right)$ and a silica gel desiccator $\left(27.19^{\circ} \mathrm{C} \pm 1.28\right.$ and $\left.26.19 \% \pm 0.94 \mathrm{RH}\right)$ for different times $(0,12,24,36,72$, and 144 hours $)$. A completely randomized design in a 2 (drying methods) $\times 5$ (drying times) factorial scheme plus control and 4 replications of 25 seeds was used. The following variables were evaluated before and after drying: seed moisture content, percentage of germinated seeds, germination speed index, percentage of mortality, normal and abnormal seedlings. In the storage experiment the seeds were divided into two batches: pre-dried (at 5.0\% humidity) and without drying (control at $8.9 \%$ humidity). The seeds were then stored in plastic bags in three environments: refrigerator at $5{ }^{\circ} \mathrm{C}$, freezer at $-20{ }^{\circ} \mathrm{C}$ and room temperature $\left(29^{\circ} \mathrm{C}\right)$. The seeds were removed every four months and submitted to the humidity and germination test for 24 months. Data from this storage experiment were analyzed considering a randomized block design in a 2 (drying levels: presence and absence) $\times 3$ (storage environments: refrigerator, freezer or room temperature) factorial scheme +2 controls (with and without drying at baseline) and 4 repetitions of 25 seeds. Drying reduced initial seed water content from $8.9 \%$ to $5.0 \%$, without loss of viability. Drying in the chamber at $40{ }^{\circ} \mathrm{C}$ was faster and more efficient than in silica gel. The results enable classifying the seeds of this species as orthodox, i.e. tolerant to desiccation. The fridge and freezer were efficient for storing the Melanoxylon brauna seeds up to 24 months, independent of previous drying, while storing the seeds at room temperature with previous drying makes them last longer than without drying, as the seeds can last up to 16 months with drying, or 12 months without drying.
\end{abstract}

Keywords: orthodox, conservation, seed technology, fabaceae.

\section{Secagem e armazenamento de sementes de Melanoxylon brauna Schott.}

\section{Resumo}

O objetivo deste trabalho foi avaliar a sensibilidade das sementes da leguminosa arbórea Melanoxylon brauna Schott à dessecação e ao armazenamento. No experimento de secagem as sementes de braúna foram submetidas a duas condições de secagem: câmara com circulação forçada de ar $\left(40,18{ }^{\circ} \mathrm{C} \pm 0,13\right.$ e 28,48\% $\left.\pm 3,95 \mathrm{UR}\right)$ e dessecador com sílica gel $\left(27,19^{\circ} \mathrm{C} \pm 1,28\right.$ e $\left.26,19 \% \pm 0,94 \mathrm{UR}\right)$, por diferentes tempos $(0,12,24,36,72,144$ horas $)$. Foi utilizado delineamento experimental inteiramente casualizado, em esquema fatorial 2 (método de secagem) $\times 5$ (tempo de secagem), mais a testemunha, com 4 repetições de 25 sementes. Foram avaliadas as seguintes variáveis antes e depois da secagem: teor de umidade da semente, porcentagem de sementes germinadas, índice de velocidade de germinação, porcentagem de mortalidade, de plântulas normais e de anormais. No experimento de armazenamento as sementes foram divididas em dois lotes: com secagem prévia (a 5,0\% de umidade) e sem secagem (testemunha, a 8,9\% de umidade), e foram armazenadas em embalagens sacos de plástico em três ambientes: geladeira a $5{ }^{\circ} \mathrm{C}$, freezer a $-20{ }^{\circ} \mathrm{C}$ e temperatura ambiente $\left(29^{\circ} \mathrm{C}\right)$. A cada quatro meses as sementes foram retiradas e submetidas ao teste de umidade e de germinação durante 24 meses. Os resultados foram avaliados por meio do delineamento em blocos casualizados, com 4 repetições de 25 sementes, em esquema fatorial 2 (secagem) $\times 3$ (ambiente de armazenamento) +2 testemunhas. A secagem proporcionou a redução do teor de água inicial das sementes de $8,9 \%$ até $5,0 \%$, sem perda da sua viabilidade. A secagem na câmara a $40^{\circ} \mathrm{C}$ foi mais rápida e eficiente do que na sílica gel. Os resultados permitem classificar as sementes desta 
espécie como ortodoxas, ou seja, tolerantes à dessecação. A geladeira e o freezer foram eficientes para o armazenamento das sementes de braúna, até 24 meses, independente da secagem prévia das sementes, enquanto o armazenamento das sementes a temperatura ambiente é mais duradouro quando as sementes são submetidas previamente à secagem, podendo durar até 16 meses com secagem ou 12 meses sem secagem.

Palavras-chave: ortodoxas, conservação, tecnologia de sementes, fabaceae.

\section{Introduction}

Melanoxylon brauna Schott, popularly known as brauna or black-brauna, is an endemic species from Brazil native to the Caatinga, Cerrado and Mata Atlântica biomes (Lima, 2015; Rando et al., 2019). It is a slow growing species and can reach up to $25 \mathrm{~m}$ in height, with its wood being used in heavy and exposed construction works, in manufacturing beams, posts and wooden sleepers because it is considered as one of the most resistant materials to attack from xylophagous organisms and also has high density (Carvalho, 2010). It is currently in a vulnerable threatened state due to the large exploitation its timber has suffered for use in construction (CNC Flora, 2012). It has beekeeping potential, produces good quality firewood and charcoal, is used in landscaping due to its beautiful yellow flowering and is also indicated for recovering degraded areas and permanent preservation (Lorenzi, 1992). Its roots are associated with bacteria of the Rhyzobium genus forming nodules (Faria et al., 1984).

A series of physiological, physical and biochemical changes occur in a progressive rhythm from the seeds physiologically maturing, determining a decrease in their performance potential and culminating in the seed death (Marcos-Filho, 2005). In this context, storage is an important method for maintaining seed longevity over time (Parrella, 2011).

Seeds of plant species have different behaviors regarding desiccation and storage, and this should be investigated in order to propose species-specific conservation protocols. Roberts (1973) classified seeds as orthodox and recalcitrant, with the former tolerating drying well to a level of 2 to $7 \%$ (Fonseca and Freire, 2003; Villela and Peres, 2004), and recalcitrant tolerating drying to levels of $15 \%$ to $50 \%$ humidity, or often do not tolerate moisture loss. Ellis et al. (1990) proposed a third category called intermediate, in which seeds allow moisture reduction down to 7 to $13 \%$, and are intolerant to freezing temperatures for storage such as $-20{ }^{\circ} \mathrm{C}$ (Ferreira and Santos, 1993; Fonseca and Freire, 2003).

Different responses of Fabaceae family seeds to dehydration are known (Roberts, 1973; Pritchard et al., 1995; Bilia et al., 1999; Barbedo et al., 2002; Bonjovani and Barbedo, 2008). Melanoxylon brauna seeds have been cited as recalcitrant (Carvalho, 2010) or as having short-term storage viability (Lorenzi, 1992).

Storage can be influenced by several factors such as initial seed moisture content, packing and storage environment, such that the period in which viability can be maintained varies from a few weeks to months or even years (Villela and Peres, 2004; Nery et al., 2017).
Seed conservation potential can be increased with seed drying as it promotes a reduction in metabolism and the incidence of pests or diseases, increasing seed storage capacity in low temperature environments (Walters, 1998). Seed drying can be done naturally or artificially. In natural drying, the seeds are dried outdoors in full sun or shade. Artificial drying can be done in a desiccator with silica gel or in a chamber using continuous or intermittent heated air flow. Several temperature ranges can be used in chamber which typically range from 40 to $60{ }^{\circ} \mathrm{C}$. Although artificial drying requires appropriate equipment and demands higher energy consumption, it has the advantage of occurring in a shorter period with greater efficiency and regardless of weather conditions. Thus, it is widely adopted in places with rainy weather such as the Amazon (Villela and Peres, 2004).

In view of the above, the present work aims to analyze the desiccation tolerance of Melanoxylon brauna seeds and their storage potential.

\section{Material and Methods}

\subsection{Drying experiment}

Melanoxylon brauna seeds were collected in October 2016 in the municipality of Leopoldina (MG) and stored in a refrigerator at $5^{\circ} \mathrm{C}$ for two months until the beginning of the experiment. The fruits were benefited and any seeds damaged by insects were identified and discarded.

The weight of one thousand seeds was determined in the laboratory according to the Seed Analysis Rules (SAR) (Brasil, 2009). The seeds were then submitted to drying under two conditions to evaluate their sensitivity to desiccation level: a forced air circulation chamber at $40{ }^{\circ} \mathrm{C}$ and a desiccator containing silica gel at room temperature. The seeds were submitted to five drying times for each drying condition: T1 - 12 hours, T2 - 24 hours, T3 - 36 hours, T4 - 72 hours, and T5 - 144 hours. Water content and seed germination percentage were then evaluated after the seeds had been submitted to each drying time. The control treatment was not submitted to drying.

The seed water content was evaluated by the greenhouse method at $105 \pm 3^{\circ} \mathrm{C}$ for 24 hours, with two repetitions of $5 \mathrm{~g}$ each (Brasil, 2009). Seed germination was evaluated by a paper-roll test with four replications of 25 seeds in a B.O.D. chamber at a constant temperature of $30{ }^{\circ} \mathrm{C}$ with a photoperiod of 12 hours. Seeds were disinfected for 30 seconds in alcohol prior to the germination test, followed by 5 minutes in $1 \%$ sodium hypochlorite, and washed in distilled water.

Germination was evaluated every three days in the first two weeks and weekly after it stabilized. The percentage 
of germinated seeds (considering the biological criterion of radicle emission with a minimum size of $2 \mathrm{~mm}$ ) and the percentage of dormant seeds, percentage of dead seeds, as well as the percentage of normal and abnormal seedlings were recorded. The Germination Speed Index (GSI) was subsequently calculated from the number of germinated seeds over time (Maguire, 1962).

The temperature and humidity of the drying environments were recorded every hour using a thermohygrograph during the desiccation experiment period (13/12 to $18 / 12 / 2016)$. The average temperature and humidity of the chamber was $40.18^{\circ} \mathrm{C} \pm 0.13,28.48 \% \pm 3.95$, and the desiccator was $27.19^{\circ} \mathrm{C} \pm 1.28$ and $26.19 \% \pm 0.94$, respectively (Figure 1).

The experimental design used in the drying experiment was completely randomized. with four replications of 25 seeds, in a 2 (drying conditions) $\times 5$ (drying times) factorial scheme +1 control (without drying). The results were subjected to analysis of variance at $5 \%$ probability. The averages of the drying conditions were compared by the variance analysis F-test (ANOVA) and the polynomial regression models were adjusted to the time levels when there was significance of this factor in the $5 \%$ probability
ANOVA. The R Program (R Development Core Team, 2018) was used to perform the statistical analyses.

\subsection{Storage experiment}

The seeds were collected in the city of Alegre (ES) in October 2016, and were stored in a refrigerator at $5{ }^{\circ} \mathrm{C}$ for two months until the beginning of the experiment. The brauna seed samples were divided into two parts, one of which was previously dried in a forced air circulation chamber at $40{ }^{\circ} \mathrm{C}$ for 144 hours, until reaching approximately $5 \%$ of water. Then the seeds "with drying" and "without drying" were stored in plastic bags in three different environments: freezer $\left(-20^{\circ} \mathrm{C}\right)$, refrigerator $\left(4.31 \pm 1.8^{\circ} \mathrm{C}\right.$; $32.2 \% \mathrm{RH} \pm 6.5)$, and the laboratory ambient temperature $\left(28.9{ }^{\circ} \mathrm{C} \pm 3.6 ; 51.9 \% \mathrm{RH} \pm 9.4\right)$. Dry and non-dried seeds were evaluated at zero storage time (control), and at 4, 8, 12, 16, 20 and 24 months of storage in relation to seed moisture content and germination, following the methodology of the drying experiment. The experimental design was randomized blocks consisting of a 2 (with and without drying) $\times 3$ (storage environments) $\times 6$ (storage times) factorial scheme +2 controls (without storage with

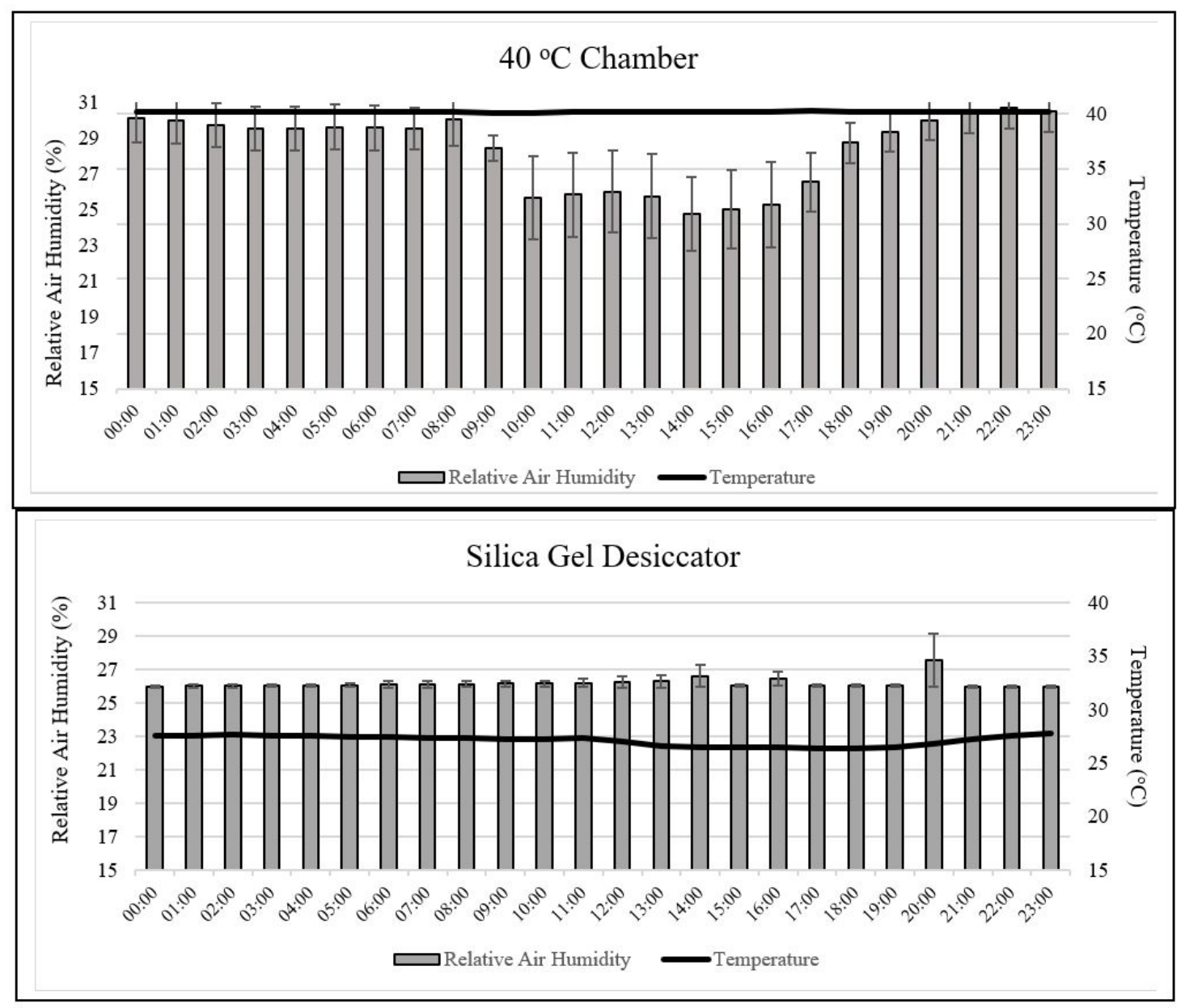

Figure 1. Average relative humidity (\%) and daily temperature of drying environments $\left(40{ }^{\circ} \mathrm{C}\right.$ chamber and silica gel desiccator) obtained by thermohygrograph during the experiment period. 
and without drying), with four repetitions of 25 seeds. The results were subjected to analysis of variance and the means were compared by the Scott-Knott test and the polynomial regression models were adjusted to the time levels, at 5\% probability, using R Program (R Development Core Team, 2018).

\section{Results}

\subsection{Drying experiment}

The $M$. brauna seeds presented initial moisture content of $8.9 \%$ (control), which significantly reduced $(\mathrm{p}<0.01)$ to $5.2 \%$ after 144 hours of drying in the chamber at $40{ }^{\circ} \mathrm{C}$, and to $6.9 \%$ in the silica gel at room temperature (Table 1). There was a significant difference between the average moisture content of the control (without drying) and the average for $36 \mathrm{~h}, 72 \mathrm{~h}$ and $144 \mathrm{~h}$ drying in both the chamber at $40{ }^{\circ} \mathrm{C}$ and silica gel (Table 1 ).

The germination percentage, mortality and Germination Speed Index of the 'Silica gel, $12 \mathrm{~h}$ ' treatment statistically differed from the mean values obtained in the control. The normal and abnormal seedling variables presented significant differences in relation to the control only for the "Silica gel, 24h" and "Chamber $40^{\circ} \mathrm{C}, 36 \mathrm{~h}$ " treatments, respectively; however, this may have been due to fungal contamination, especially in the seedling phase.

Germination percentage, mortality rate and Germination Speed Index were not affected by drying method or time independent. The other variables, normal and abnormal seedlings, showed some significant differences, but this may have been due to fungal contamination, especially in the seedling phase.
The dried seeds presented a germination variation between $68 \%$ (control) and $87 \%$ in silica gel, with significant difference between control and the 12 hours drying treatment (Table 1).

The loss of seed moisture through drying in the forced air circulation chamber at $40{ }^{\circ} \mathrm{C}$ was more efficient than that performed in the desiccator containing silica gel at 36,72 and $144 \mathrm{~h}$ drying times, resulting in significant differences of $1.1 \%, 0.7 \%$ and $1.7 \%$ in moisture content, respectively (Table 2 ).

The silica gel presented significantly better results than the cold chamber for the GSI and abnormal plant percentage variables, but only at 72 hours (average 3.2 vs. 2.2) and 36 hours (average $0 \%$ vs. $8 \%$ ) of drying, respectively. Only 144 hours of drying showed a statistical differentiation between chamber drying methods $(29 \%)$ at $40{ }^{\circ} \mathrm{C}$ and silica gel $(9 \%)$ for the percentage of normal seedlings. There were no significant differences between the drying methods for the germination and mortality rates of brauna seeds, regardless of storage time (Table 1).

Figure 2 shows the regression graph between the moisture content and germination variables at the different drying times under the two drying conditions. The moisture content in silica gel decreases $0.012 \%$ every hour, while the moisture content $(\%)$ in the $40{ }^{\circ} \mathrm{C}$ chamber was estimated at the maximum $(10 \%)$ at the time of $101 \mathrm{~h}$, and at the minimum $(2 \%)$ at the time of $61 \mathrm{~h}$.

\subsection{Storage experiment}

In the storage experiment, the M. brauna seeds after previous drying presented moisture content of $5.003 \% \pm 0.112$, and germination of $85 \%$. Seeds without initial drying showed $8.864 \% \pm 0.148$, and germination of $87 \%$.

Table 1. Germination Percentage (G), Germination Speed Index (GSI), Normal Seedling Percentage (NSP), Abnormal Seedling Percentage (ASP), Mortality (Mort), and Moisture Content Percentage (MCP) for different times and drying conditions for brauna (Melanoxylon brauna) seeds compared to control.

\begin{tabular}{lcccccc}
\hline \multicolumn{1}{c}{ Treatment } & G & GSI & NSP & ASP & Mort & MCP \\
\hline Control & 68 & 2.8 & 14 & 0 & 32 & 8.9 \\
$40^{\circ} \mathrm{C}$ Chamber, 12h & 80 & 3.3 & 12 & 0 & 20 & 8.2 \\
$40^{\circ} \mathrm{C}$ Chamber, 24h & 71 & 2.8 & 13 & 0 & 29 & 8.3 \\
$40^{\circ} \mathrm{C}$ Chamber, 36h & 80 & 2.9 & 7 & $8^{*}$ & 20 & $6.4^{* * *}$ \\
$40^{\circ} \mathrm{C}$ Chamber, 72h & 72 & 2.2 & 15 & 3 & 28 & $6.6^{* * *}$ \\
$40^{\circ} \mathrm{C}$ Chamber, 144h & 81 & 3.2 & 29 & 2 & 19 & $5.2^{* * *}$ \\
Silica Gel, 12h & $87^{*}$ & $3.6^{\circ}$ & 11 & 1 & $13^{*}$ & 8.2 \\
Silica Gel, 24h & 76 & 2.9 & $33^{*}$ & 2 & 24 & 8.9 \\
Sílica Gel, 36h & 75 & 2.9 & 0 & 0 & 25 & $7.5^{* *}$ \\
Silica Gel, 72h & 77 & 3.2 & 17 & 7 & 23 & $7.3^{* * *}$ \\
Silica Gel, 144h & 80 & 3.1 & 9 & 0 & 20 & $6.9^{* * *}$ \\
\hline
\end{tabular}

***, *'; Significant mean relative to control at $0.1 \%, 5 \%$ and $10 \%$ probability, respectively.

Table 2. Moisture content (\%) of brauna (Melanoxylon brauna) seeds submitted to five drying times (12 to 144 hours) in $40{ }^{\circ} \mathrm{C}$ Chamber and Silica Gel Desiccator.

\begin{tabular}{lcccccc}
\hline \multirow{2}{*}{ Drying condition } & \multicolumn{7}{c}{ Drying time (hours) } \\
\cline { 2 - 7 } & $\mathbf{1 2}$ & $\mathbf{2 4}$ & $\mathbf{3 6}$ & $\mathbf{7 2}$ & $\mathbf{1 4 4}$ & Overall mean \\
\hline $40^{\circ} \mathrm{C}$ Chamber & $8.2^{\mathrm{a}}$ & $8.3^{\mathrm{a}}$ & $6.4^{\mathrm{a}}$ & $6.6^{\mathrm{a}}$ & $5.2^{\mathrm{a}}$ & $7.0^{\mathrm{a}}$ \\
Silica Gel & $8.2^{\mathrm{a}}$ & $8.9^{\mathrm{a}}$ & $7.5^{\mathrm{b}}$ & $7.3^{\mathrm{b}}$ & $6.9^{\mathrm{b}}$ & $7.8^{\mathrm{b}}$ \\
\hline
\end{tabular}

Mean followed by equal letters in the column do not differ from each other by the F-test at $5 \%$ significance. 


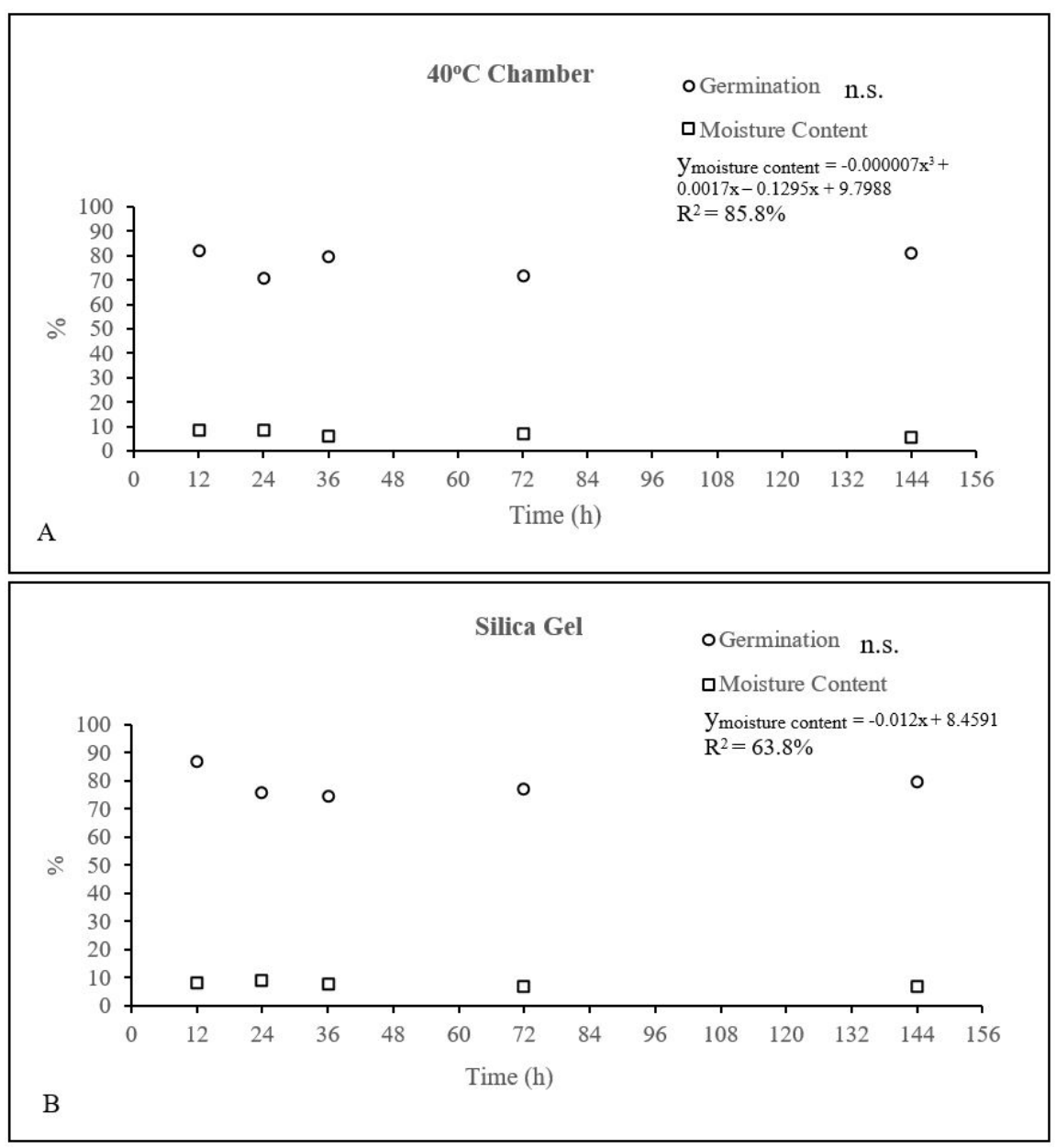

Figure 2. Regression analysis considering germination results and moisture content obtained at different drying times for Melanoxylon brauna seeds in $40^{\circ} \mathrm{C}$ Chamber (A) and Silica Gel Desiccator (B). n.s. $=$ no significative.

The triple interaction between drying, environment and storage time was significant $(\mathrm{p}<0.05)$ for the variables seed moisture, Germination Speed Index, percentage of normal and abnormal seedlings, thus indicating a dependence between them. The significance for germination and mortality percentage occurred for the double interactions between storage and drying environment, and between environment and storage time. Undried seeds stored at room temperature were the first to significantly lose viability (Figure 3). At up to eight months of storage, non-dried seeds stored at room temperature maintained $85 \%$ germination, close to the initial germination $(86 \%)$ - Table 3 . Germination reduction at room began to be detected at 12 months, when it fell to $73,8 \%$, and then successively decreased at each assessment, with $66,3 \%$ at 16 months, $4,3 \%$ at 20 months, and finally $1 \%$ at 24 months. In turn, seeds dried and stored at room temperature presented germination close to the initial until 12 months. Its decrease was detected at 16 months of storage when it fell to $79 \%$, and then to $30 \%$ and $15 \%$ at 20 and 24 months, respectively (Table 3 and Figure 3).
No germination decrease was detected for refrigerator $\left(4{ }^{\circ} \mathrm{C}\right)$ and freezer $\left(-20^{\circ} \mathrm{C}\right)$ environments with or without drying up to 24 months of storage. This shows that these conditions were favorable to conserving physiological seed quality (Figure 3 ).

The Germination Speed Index (GSI) and mortality showed the same behavior as germination, with reduced GSI and increased mortality (data not shown) from the $12^{\text {th }}$ month for non-dried seeds stored at room temperature, and consequently worse performance of this storage environment compared to freezer and refrigerator from this date.

Some other differences were noted which were punctual, such as the lowest GSI and germination (Table 3 ) at 4 months, and higher mortality (data not shown) of the dry seeds stored in the refrigerator compared to the non-dry seeds of this same environment, and lower GSI of non-dried seeds from the natural environment compared to dry seeds (Table 3 ). The dried seeds stored in the freezer presented lower physiological quality at 20 months than the non-dried seeds of this environment, which was observed by the lower GSI and higher mortality (Table 3 ). 
The dried seeds were stored with initial moisture content of $5.0 \%$ and subsequently presented moisture content of $6.5 \%$ in the freezer, $7.5 \%$ in the refrigerator and $8.7 \%$ at room temperature (Table 4; Figure 4) after 24 months.
The environment which caused the greatest variation in humidity was natural, regardless of the drying type, with this oscillation being more evident in non-dried seeds $(\delta=0.74)$ than in dry seeds $(\delta=0.63)$. The freezer was the

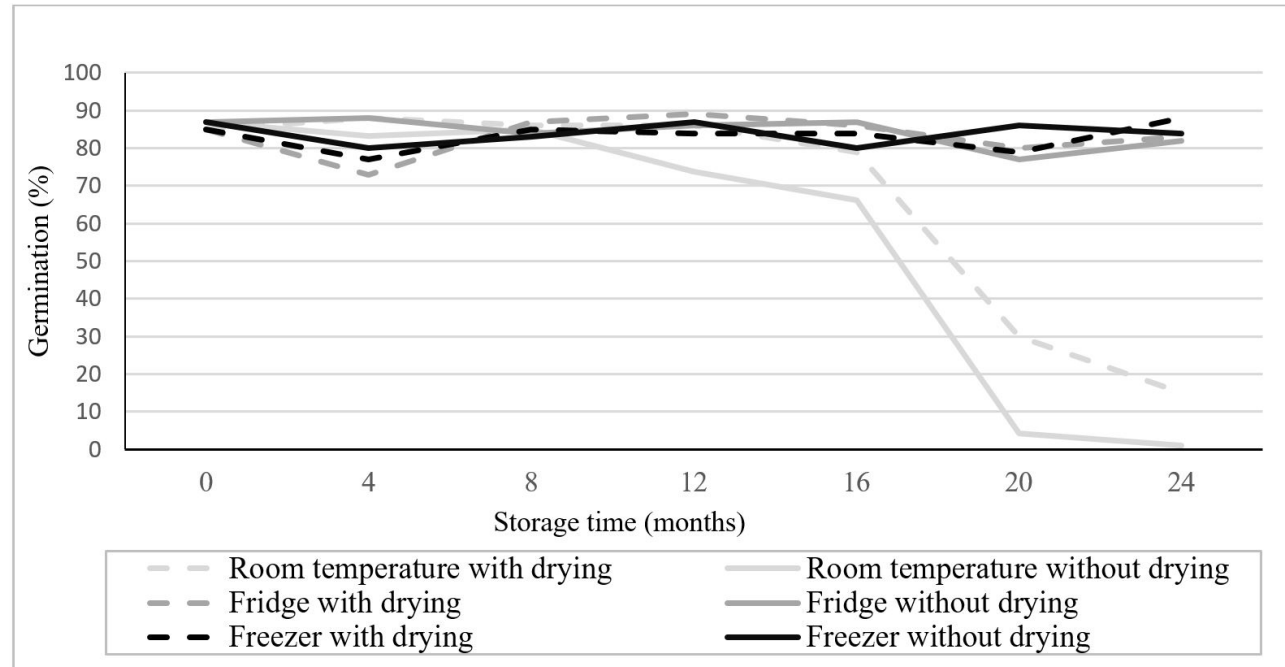

Figure 3. Germination variation (\%) of Melanoxylon brauna seeds stored in different environments for 24 months with or without previous drying.

Table 3. Germination percentage, Germination Speed Index (GSI) and mortality (MORT) values of Melanoxylon brauna seeds with and without drying stored in the freezer (Freez), refrigerator (Fridge) and room temperature (Room) for $24 \mathrm{months}$.

\begin{tabular}{|c|c|c|c|c|c|c|c|c|c|c|c|c|c|}
\hline \multirow{2}{*}{ 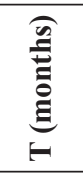 } & \multirow[b]{2}{*}{ Drying } & \multicolumn{4}{|c|}{ GERMINATION (\%) } & \multicolumn{4}{|c|}{ GSI } & \multicolumn{4}{|c|}{ Mort } \\
\hline & & reez & e & $n$ & n & & ridge & Ro & n & $\mathbf{Z}$ & ridge & Room & Mean \\
\hline \multirow{3}{*}{4} & & $77.0^{\mathrm{bA}}$ & $13.0^{\circ 0}$ & 0.0 & . & & $3.3^{\mathrm{bB}}$ & & & & $27.0^{0.12}$ & & 20.1 \\
\hline & No & $80.0^{\mathrm{aA}}$ & $88.0^{\mathrm{aA}}$ & $83.3^{\mathrm{aA}}$ & $83.8^{\mathrm{A}}$ & $3.8^{\mathrm{aA}}$ & $4.1^{\mathrm{aA}}$ & $3.4^{\mathrm{bB}}$ & $3.8^{A}$ & $20.0^{\mathrm{aA}}$ & $12.0^{\mathrm{bA}}$ & $16.8^{\mathrm{aA}}$ & $16.3^{A}$ \\
\hline & Mean & $78.5^{a}$ & $80.5^{a}$ & $85.6^{\mathrm{a}}$ & & $3.6^{a}$ & $3.73^{a}$ & $3.8^{\mathrm{a}}$ & & $21.5^{\mathrm{a}}$ & $19.5^{\mathrm{a}}$ & $14.4^{\mathrm{a}}$ & \\
\hline \multirow{3}{*}{8} & With & $85.0^{\mathrm{aA}}$ & $87.0^{\mathrm{aA}}$ & $86.0^{\mathrm{aA}}$ & $86.0^{A}$ & $4.1^{\mathrm{aA}}$ & $4.1^{\mathrm{aA}}$ & $4.1^{\mathrm{aA}}$ & $4.1^{\mathrm{A}}$ & $15.0^{\mathrm{aA}}$ & $13.0^{\mathrm{aA}}$ & $14.0^{\mathrm{aA}}$ & $14.0^{A}$ \\
\hline & No & $83.0^{\mathrm{aA}}$ & $84.0^{\mathrm{aA}}$ & $85.0^{\mathrm{aA}}$ & $84.0^{A}$ & $3.9^{\mathrm{aA}}$ & $4.1^{\mathrm{aA}}$ & $4.0^{\mathrm{aA}}$ & $4.0^{A}$ & $17.0^{\mathrm{aA}}$ & $16.0^{\mathrm{aA}}$ & $15.0^{\mathrm{aA}}$ & $16.0^{A}$ \\
\hline & Mean & $84.0^{\mathrm{a}}$ & $85.5^{\mathrm{a}}$ & $85.5^{\mathrm{a}}$ & & $4.0^{\mathrm{a}}$ & $4.1^{\mathrm{a}}$ & $4.0^{\mathrm{a}}$ & & $16.0^{\mathrm{a}}$ & $14.5^{\mathrm{a}}$ & $14.5^{\mathrm{a}}$ & \\
\hline \multirow{3}{*}{12} & With & $84.0^{\mathrm{aA}}$ & $89.0^{\mathrm{aA}}$ & $86.0^{\mathrm{aA}}$ & $86.3^{\mathrm{A}}$ & $4.1^{\mathrm{aA}}$ & $4.1^{\mathrm{aA}}$ & $0.4^{\mathrm{bB}}$ & $2.9^{\mathrm{B}}$ & $16.0^{\mathrm{aA}}$ & $11.0^{\mathrm{aA}}$ & $14.0^{\mathrm{aB}}$ & $13.7^{A}$ \\
\hline & No & $87.0^{\mathrm{aA}}$ & $86.0^{\mathrm{aA}}$ & $73.8^{\mathrm{bB}}$ & $82.3^{\mathrm{A}}$ & $4.2^{\mathrm{aA}}$ & $4.2^{\mathrm{aA}}$ & $3.0^{\mathrm{bA}}$ & $3.8^{\mathrm{A}}$ & $13.0^{\mathrm{bA}}$ & $14.0^{\mathrm{bA}}$ & $26.3^{\mathrm{aA}}$ & $17.8^{A}$ \\
\hline & Mean & $85.5^{\mathrm{a}}$ & $87.5^{a}$ & $79.9^{a}$ & & $4.1^{\mathrm{a}}$ & $4.2^{\mathrm{a}}$ & $1.7^{\mathrm{b}}$ & & & $12.5^{\mathrm{a}}$ & $20.1^{\mathrm{a}}$ & \\
\hline \multirow{3}{*}{16} & With & $84.0^{\mathrm{aA}}$ & $86.0^{\mathrm{aA}}$ & $79.0^{\mathrm{aA}}$ & $83.0^{A}$ & $4.2^{\mathrm{aA}}$ & $4.2^{\mathrm{aA}}$ & $3.8^{\mathrm{aA}}$ & $4.1^{\mathrm{A}}$ & $16.0^{\mathrm{aA}}$ & $14.0^{\mathrm{aA}}$ & $21.0^{\mathrm{aB}}$ & $17.0^{A}$ \\
\hline & No & $80.0^{\mathrm{aA}}$ & $87.0^{\mathrm{aA}}$ & $66.3^{\mathrm{bB}}$ & $77.8^{\mathrm{A}}$ & $3.9^{\mathrm{aA}}$ & $4.3^{\mathrm{aA}}$ & $2.9^{\mathrm{bB}}$ & $3.7^{\mathrm{B}}$ & $20.0^{\mathrm{bA}}$ & $13.0^{\mathrm{bA}}$ & $33.8^{\mathrm{aA}}$ & $22.3^{A}$ \\
\hline & Mean & $82.0^{\mathrm{a}}$ & $86.5^{\mathrm{a}}$ & $72.6^{\mathrm{b}}$ & & $4.1^{\mathrm{a}}$ & $4.3^{\mathrm{a}}$ & $3.4^{\mathrm{b}}$ & & $18.0^{b}$ & $13.5^{\mathrm{b}}$ & $27.4^{\mathrm{a}}$ & \\
\hline \multirow{3}{*}{20} & With & $79.0^{\mathrm{aA}}$ & $80.0^{\mathrm{aA}}$ & $30.0^{\mathrm{bA}}$ & $63.0^{A}$ & $3.5^{\mathrm{aB}}$ & $3.8^{\mathrm{aA}}$ & $0.9^{\mathrm{bA}}$ & $2.7^{\mathrm{A}}$ & $21.0^{\mathrm{bA}}$ & $20.0^{\mathrm{bA}}$ & $70.0^{\mathrm{aB}}$ & $37.0^{B}$ \\
\hline & No & $86.0^{\mathrm{aA}}$ & $77.0^{\mathrm{aA}}$ & $4.3^{\mathrm{bB}}$ & $55.8^{\mathrm{B}}$ & $4.2^{\mathrm{aA}}$ & $3.6^{\mathrm{bA}}$ & $0.1^{\mathrm{cB}}$ & $2.6^{\mathrm{A}}$ & $14.0^{\mathrm{bA}}$ & $23.0^{\mathrm{bA}}$ & $95.8^{\mathrm{aA}}$ & $44.3^{\mathrm{A}}$ \\
\hline & Mean & $82.5^{a}$ & $78.5^{a}$ & $17.1^{\mathrm{b}}$ & & $3.9^{\mathrm{a}}$ & $3.7^{\mathrm{a}}$ & $0.5^{b}$ & & $17.5^{\mathrm{b}}$ & $21.5^{\mathrm{b}}$ & $82.9^{\mathrm{a}}$ & \\
\hline \multirow{3}{*}{24} & With & $88.0^{\mathrm{aA}}$ & $83.0^{\mathrm{aA}}$ & $15.0^{\mathrm{bA}}$ & $62.0^{A}$ & $4.4^{\mathrm{aA}}$ & $4.1^{\mathrm{aA}}$ & $0.5^{\mathrm{bA}}$ & $3.0^{A}$ & $12.0^{\mathrm{bA}}$ & $17.0^{\mathrm{bA}}$ & $85.0^{\mathrm{Ab}}$ & $38.0^{\mathrm{B}}$ \\
\hline & No & $84.0^{\mathrm{aA}}$ & $82.0^{\mathrm{aA}}$ & $1.0^{\mathrm{bB}}$ & $55.7^{\mathrm{B}}$ & $4.1^{\mathrm{aA}}$ & $4.0^{\mathrm{aA}}$ & $0.05^{\mathrm{bA}}$ & $2.7^{\mathrm{A}}$ & $16.0^{\mathrm{bA}}$ & $18.0^{\mathrm{bA}}$ & $99.0^{\mathrm{aA}}$ & $44.3^{\mathrm{A}}$ \\
\hline & Mean & $86.0^{a}$ & $82.5^{a}$ & $8.0^{b}$ & & $4.2^{\mathrm{a}}$ & $4.1^{\mathrm{a}}$ & $0.3^{b}$ & & $14.0^{b}$ & $17.5^{\mathrm{b}}$ & $92.0^{a}$ & \\
\hline \multirow{3}{*}{ Mean } & With & $82.8^{\mathrm{aA}}$ & $83.0^{\mathrm{aA}}$ & $64.0^{\mathrm{bA}}$ & $76.6^{A}$ & $3.9^{\mathrm{aA}}$ & $3.9^{\mathrm{aA}}$ & $2.3^{\mathrm{bA}}$ & $3.4^{\mathrm{A}}$ & $17.2^{\mathrm{bA}}$ & $17.0^{\mathrm{bA}}$ & $36.0^{\mathrm{Ab}}$ & $23.4^{\mathrm{B}}$ \\
\hline & No & $83.3^{\mathrm{aA}}$ & $84.0^{\mathrm{aA}}$ & $52.3^{\mathrm{bB}}$ & $73.2^{\mathrm{B}}$ & $4.1^{\mathrm{aA}}$ & $4.0^{\mathrm{aA}}$ & $2.2^{\mathrm{bA}}$ & $3.4^{\mathrm{A}}$ & $16.7^{\mathrm{bA}}$ & $16.0^{\mathrm{bA}}$ & $47.7^{\mathrm{aA}}$ & $26.8^{A}$ \\
\hline & Mean & $83.1^{\mathrm{a}}$ & $83.5^{a}$ & $58.1^{\mathrm{b}}$ & & $4.0^{\mathrm{a}}$ & $4.0^{\mathrm{a}}$ & $2.3^{b}$ & & $16.9^{b}$ & $16.5^{b}$ & $41.8^{a}$ & \\
\hline
\end{tabular}

Germination Speed Index (GSI); Mortality (Mort). Means followed by distinct letters, lowercase letters (between environments) and uppercase letters (between with and without drying) differ by the Scott-Knott grouping method and F-test, respectively, at 5\% probability. 
Table 4. Moisture content of brauna seeds stored with and without drying in the freezer, refrigerator and room temperature for 24 months.

\begin{tabular}{|c|c|c|c|c|c|}
\hline \multirow{2}{*}{ TIME (months) } & \multirow{2}{*}{ Drying } & \multicolumn{4}{|c|}{ Seed Moisture Content (\%) } \\
\hline & & Freezer & Fridge & Room & Mean \\
\hline \multirow{3}{*}{4} & With & $6.5^{\mathrm{bB}}$ & $6.2 \mathrm{bB}$ & 8.7 а в & $7.1^{\mathrm{A}}$ \\
\hline & No & $9.8^{\mathrm{aA}}$ & $8.9^{\mathrm{bA}}$ & $9.8^{\text {a A }}$ & $9.2^{\mathrm{A}}$ \\
\hline & Mean & $8.8^{b}$ & $9.0^{b}$ & $9.5^{\text {a }}$ & \\
\hline \multirow{3}{*}{8} & With & $7.5^{\mathrm{b} \mathrm{B}}$ & $7.8^{\text {b в }}$ & $10.3^{\mathrm{aA}}$ & $8.5^{\text {в }}$ \\
\hline & No & $11.0^{\mathrm{aA}}$ & $10.5^{\mathrm{aA}}$ & $10.6^{\mathrm{aA}}$ & $10.7^{\mathrm{A}}$ \\
\hline & Mean & $9.3^{b}$ & $9.1^{b}$ & $10.4^{a}$ & \\
\hline \multirow{3}{*}{12} & With & $7.0^{\mathrm{b} \mathrm{B}}$ & $7.5^{\text {b в }}$ & $9.4^{\mathrm{aA}}$ & $8.0^{\text {B }}$ \\
\hline & No & $10.6^{\mathrm{aA}}$ & $9.9^{\mathrm{bA}}$ & $9.5^{\mathrm{bA}}$ & $10.0^{\mathrm{A}}$ \\
\hline & Mean & $8.8^{b}$ & $8.7^{b}$ & $9.4^{\mathrm{a}}$ & \\
\hline \multirow{3}{*}{16} & With & $6.6^{\mathrm{cB}}$ & $7.6^{\mathrm{b} \mathrm{B}}$ & $8.7^{\text {а в }}$ & $7.6^{\text {B }}$ \\
\hline & No & $9.9^{\mathrm{aA}}$ & $9.4^{\mathrm{a} \mathrm{A}}$ & $9.4^{\mathrm{aA}}$ & $9.5^{\mathrm{A}}$ \\
\hline & Mean & $9.6^{\mathrm{a}}$ & $9.6^{\mathrm{a}}$ & $9.7^{\mathrm{a}}$ & \\
\hline \multirow{3}{*}{20} & With & $7.4^{\mathrm{b} \mathrm{B}}$ & $7.8^{\text {в в }}$ & $8.8^{\mathrm{aA}}$ & $8.0^{\text {в }}$ \\
\hline & No & $10.0^{\mathrm{aA}}$ & $9.7^{\mathrm{aA}}$ & $9.3^{\text {a A }}$ & $9.7^{\mathrm{A}}$ \\
\hline & Mean & $8.7^{\mathrm{a}}$ & $8.8^{a}$ & $9.1^{\text {a }}$ & \\
\hline \multirow{3}{*}{24} & With & $6.5^{\mathrm{c} \mathrm{B}}$ & 7.5 b в & $8.7^{\mathrm{aA}}$ & $7.6^{\mathrm{B}}$ \\
\hline & No & $9.9^{\mathrm{aA}}$ & $9.4^{\mathrm{a} \mathrm{A}}$ & $8.3^{\mathrm{bA}}$ & $9.2^{\mathrm{A}}$ \\
\hline & Mean & $8.2^{\text {a }}$ & $8.5 \mathrm{a}$ & $8.5^{\text {a }}$ & \\
\hline \multirow{3}{*}{ Total mean } & With & $6.9^{\text {с в }}$ & $7.4^{\text {b в }}$ & $9.1^{\text {а в }}$ & $7.8^{\text {в }}$ \\
\hline & No & $10.2^{\mathrm{aA}}$ & $9.6^{\mathrm{bA}}$ & $9.5^{\mathrm{bA}}$ & $9.8^{A}$ \\
\hline & Mean & $8.6^{b}$ & $8.5^{b}$ & $9.3^{a}$ & \\
\hline \multirow{2}{*}{$\begin{array}{l}\text { Standard deviation } \\
\text { total }\end{array}$} & With & 0.44 & 0.62 & 0.63 & 0.47 \\
\hline & No & 0.46 & 0.54 & 0.74 & 0.52 \\
\hline
\end{tabular}

Means followed by distinct letters, lowercase letters (between environments), and uppercase letters column (between with and without drying) differ from each other by the method of grouping Scott-Knott and F-test, respectively, at 5\% probability.

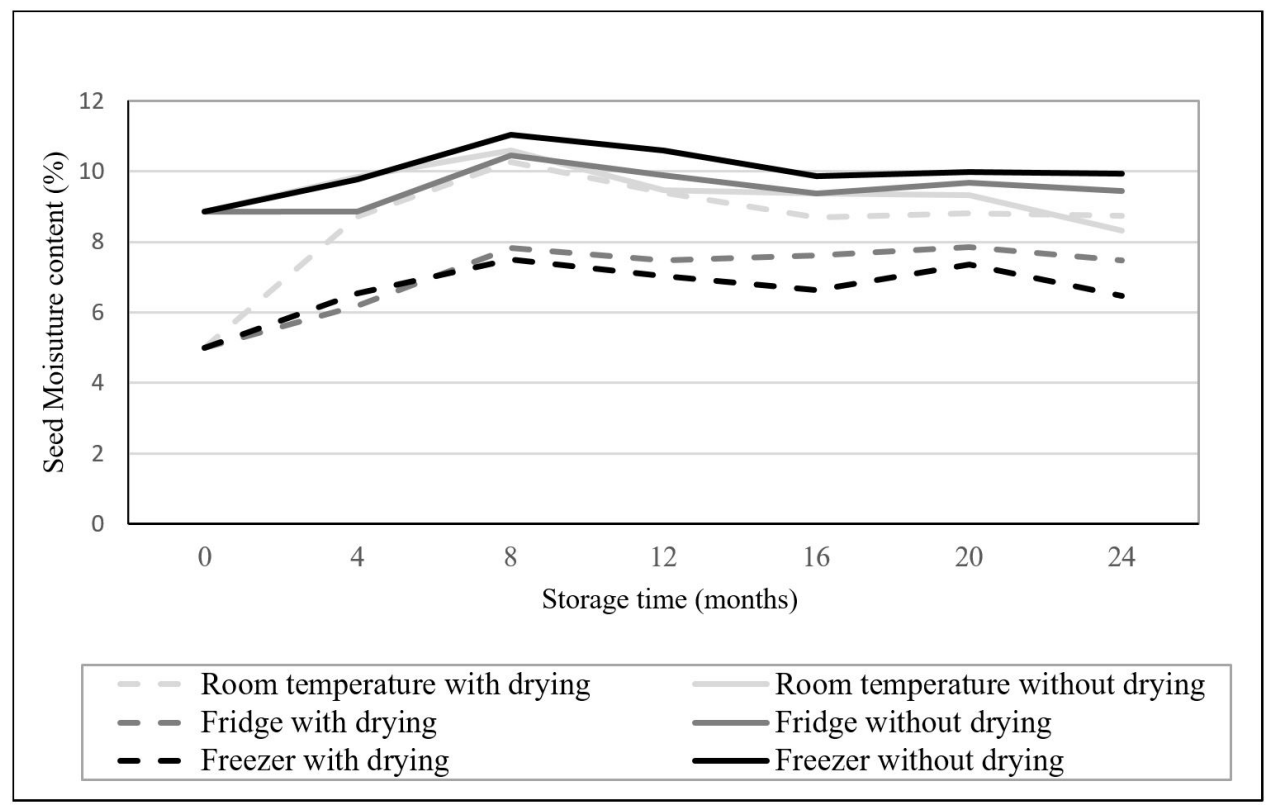

Figure 4. Melanoxylon brauna seed moisture content (\%) stored in different environments for 24 months with or without previous drying. 
environment which best preserved the low seed moisture, with little difference between dry $(\delta=0.44)$ and non-dry $(\delta=0.46)$ seeds (Table 4$)$.

\section{Discussion}

Drying is a fundamental tool for preserving orthodox seeds, since it aims to reduce metabolism, thus favoring physiological quality conservation during storage. The brauna seeds showed their ability to withstand drying at all analyzed drying times, even germinating when the moisture content was reduced to levels close to $5 \%$, which corresponds to behavior of orthodox seeds (Table 1). This result contradicts Carvalho (2010) who cites M. brauna as a recalcitrant species. In studying the desiccation tolerance and storage of Paubrasilia echinata (Lam.) Gagnon, H.C.Lima \& G.P.Lewis (Brazilwood) seeds, Barbedo et al. (2002) also classified it as orthodox, tolerating desiccation until reaching $7.6 \%$ of water. In contrast, Inga vera subsp. affinis does not tolerate water content reduction below $35 \%$, being classified as recalcitrant (Bonjovani and Barbedo, 2008).

According to Silva et al. (1993), the drying process comprises two phases: initially there is a displacement of moisture from the surface of the fruit or seed to the surrounding air, followed by moisture migration from the interior to the surface. The $\mathrm{O}_{2}$ consumption and $\mathrm{CO}_{2}$ release rates are slowly decreasing during this process, so that the seed primary metabolism is reduced, in which seeds with lower water content presented lower metabolic activity (Bragante et al., 2018).

Higher efficiency of moisture loss in the chamber was observed in drying brauna seeds, which can be attributed to the higher temperature $\left(40.18{ }^{\circ} \mathrm{C} \pm 0.13,28.48 \% \pm 3.95\right)$ than the desiccator containing silica gel $\left(27.19^{\circ} \mathrm{C} \pm 1.28\right.$ and $26.19 \% \pm 0.94)$. The highest water removal rate from seeds as room temperature increases has been observed by several researchers for forest species (Oliveira et al., 2011; Barrozo et al., 2014; Silva et al., 2014; Mendonça et al., 2019).

Seed storage in suitable locations is important for conserving population germplasm and for seedling production at different times of the year. In this context, it was found that both the refrigerator and freezer environments maintained the viability of $M$. brauna seeds during the experiment period. Dry seeds initially stored with $85 \%$ germination after 24 months maintained $88 \%$ germination in the freezer and $83 \%$ in the refrigerator, with no significant difference. Non-dried seeds with initial germination of $87 \%$ after 24 months presented $84 \%$ germination in the freezer and $82 \%$ in the refrigerator. These results do not corroborate Lorenzi (1992), who states that the species has short storage viability. M. brauna seeds stored in a cold chamber at $20^{\circ} \mathrm{C}$ and $60 \% \mathrm{RH}$ with initial germination of $97 \%$ gradually lost up to $57 \%$ after 12 months of storage (Corte et al., 2010a, 2010b). In another work on storage of M. brauna seeds, they were kept at a constant temperature of $20^{\circ} \mathrm{C}$ for 8 months and three relative humidity conditions in the environment: 55,75 and $93 \%$. The seeds stored in an environment with $55 \%$ relative humidity maintained similar germination and GSI values to the beginning of the test. Higher humidity caused a loss and physiological quality in the seeds, while in storage at $93 \%$ relative humidity the seeds lost germination at 4 months (Borges et al., 2015). This shows the importance of humidity and temperature for seed conservation.

In this work, storage at room temperature resulted in greater oscillation of the moisture content of brauna seeds, with the beginning of vigor loss at 12 months and significant loss at 20 months. The previous drying extended the viability of the brauna seeds for a further 4 months under these uncontrolled conditions. Seeds stored under natural environmental conditions are subject to a greater variation of environmental characteristics such as temperature and humidity, which have a direct influence on the seed due to its hygroscopicity. According to Kauth and Biber (2014), seed storage in environments with greater humidity variation for long periods may reduce seedling germination and survival.

Several authors have reported that vigor decreased during storage periods in uncontrolled environments, as observed for Tabebuia serratifolia at 9 months (Silva et al., 2011), Talisia esculenta at 75 days (Sena et al., 2016), Schinus terebinthifolius at 4 months (Oliveira et al., 2018a) and Vochysia divergens at 150 days (Oliveira et al., 2018b). Decreased seed physiological viability as storage time increases occurs due to the seed deterioration process. Among the changes which occur during deterioration, we can mention the progressive reduction in lipid content in the embryonic axis and seed cotyledons (Corte et al., $2010 \mathrm{a}$ ), in addition to the production of free radicals or reactive oxygen species which promote changes in enzyme structure (Mc Donald, 1999). Studies by Garcia et al. (2006) on Brazilwood seeds observed changes in soluble sugars during storage, thus suggesting that the loss of its germinability may be associated with low glucose and fructose levels in relation to sucrose.

This deterioration accelerates the natural degeneration processes of biological systems, so that the seeds lose their vigor quickly under these conditions and then their germination capacity some time later. In addition, storage in an unsuitable environment may stimulate microorganism development, reducing longevity or even causing seed death (Silva and Ferraz, 2015). On the other hand, storing seeds at an appropriate temperature can prolong seed viability. In this work, we show that brauna seeds can be stored efficiently without deterioration for at least 24 months at a temperature of $5{ }^{\circ} \mathrm{C}$ or $-18^{\circ} \mathrm{C}$, regardless of drying.

\section{Conclusion}

- Melanoxylon brauna seeds have orthodox behavior regarding drying and storage behavior;

- The forced air circulation chamber at $40{ }^{\circ} \mathrm{C}$ after 36 hours of drying was more efficient for drying than silica gel to reduce the moisture content of M. brauna seeds; 
- The refrigerator and freezer were efficient for storing M. brauna seeds for at least 24 months, regardless of previous drying of the seeds;

- Storage of M. brauna seeds at room temperature lasts longer when the seeds are previously dried, and can last up to 16 months with drying or 12 months without drying.

\section{Acknowledgements}

We thank Adriana Nascimento, Ana Lucia Ormond and Marcelo Antoniol for their support in the laboratory and Paulo Cézar Oliveira for collecting the seeds.

\section{References}

BARBEDO, C.J., BILIA, D.A. and FIGUEIREDO-RIBEIRO, R.C., 2002. Tolerância à dessecação e armazenamento de sementes de Caesalpinia echinata Lam.(pau-brasil), espécie da Mata Atlântica. Revista Brasileira de Botânica, vol. 25, no. 4, pp. 431-439. http:// dx.doi.org/10.1590/S0100-84042002012000007.

BARROZO, D.V.A., ALVES, E.U., ARAUJO, L.R., SENA, S.V.A., MEDEIROS, D.S. and SANTOS, J.C., 2014 [viewed 27 September 2019]. Qualidade fisiológica de sementes de ingá em função da secagem. Bioscience Journal [online], vol. 30, no. 3, pp. 645-654. Available from: http://www.seer.ufu.br/index.php/ biosciencejournal/article/view/18034

BILIA, D.A.C., MARCOS-FILHO, J. and NOVEMBRE, A.D.C.L., 1999. Desiccation tolerance and seed storability of Inga uruguensis (Hook. et Arn.). Seed Science and Technology, vol. 27, no. 1, pp. 77-89.

BONJOVANI, M.R. and BARBEDO, C.J., 2008. Sementes recalcitrantes: intolerantes a baixas temperaturas? Embriões recalcitrantes de Inga vera Willd. subsp. affinis (DC.) TD Penn. toleram temperatura sub-zero. Brazilian Journal of Botany, vol. 31, no. 2, pp. 345-356. http://dx.doi.org/10.1590/S010084042008000200017 .

BORGES, E.E.L., FLORES, A.V., ATAIDE, G.M. and MATOS, A.C.B., 2015. Alterações fisiológicas e atividade enzimática em sementes armazenadas de Melanoxylon brauna Schott. Cerne, vol. 21, no. 1, pp. 75-81. http://dx.doi.org/10.1590/010477602 01521011569 .

BRAGANTE, R.B., HELL, A.F., SILVA, J.P.N., CENTENO, D.C., FIGUEIREDO-RIBEIRO, R.C. and BARBEDO, C.J., 2018. Physiological and metabolic responses of immature and mature seeds of Libidibia ferrea ((Mart. ex Tul.) L.P. Queiroz) under contrasting storage temperatures. Brazilian Journal of Botany, vol. 41, no. 1, pp. 43-55. http://dx.doi.org/10.1007/ s40415-018-0442-3.

BRASIL. Ministério da Agricultura e Reforma Agrária, 2009. Regras para análise de sementes. Brasília.

CARVALHO, P.E.R., 2010. Espécies arbóreas brasileiras. 21. ed. Brasília: Embrapa Informação Tecnológica, 2010. 644 p. vol. 1.

CENTRO NACIONAL DE CONSERVAÇÃO DA FLORA CNCFlora, 2012 [viewed 27 September 2019]. Melanoxylon brauna. In: JARDIM BOTÂNICO DO RIO DE JANEIRO - JBRJ. Lista Vermelha da flora brasileira versão 2012 [online]. Rio de
Janeiro: JBRJ. Available from: http://cncflora.jbrj.gov.br/portal/ pt-br/profile/Melanoxylon\%20brauna

CORTE, V.B., BORGES, E.E.L., LEITE, H.G. and LEITE, I.T.A., 2010a. Qualidade fisiológica de sementes de Melanoxylon brauna envelhecidas natural e artificialmente. Scientia Forestalis, vol. 38 , no. 86 , pp. 181-189.

CORTE, V.B., BORGES, E.E.L., LEITE, H.G., PEREIRA, B.L.C. and GONÇALVES, J.F.C., 2010b. Estudo enzimático da deterioração de sementes de Melanoxylon brauna submetidas ao envelhecimento natural e acelerado. Revista Brasileira de Sementes, vol. 32, no. 1, pp. 83-91. http://dx.doi.org/10.1590/ S0101-31222010000100010.

ELLIS, R.H., HONG, T.D. and ROBERTS, E.H., 1990. An intermediate category of seed storage behaviour? I. Coffee. Journal of Experimental Botany, vol. 41, no. 230, pp. 1167-1174. http:// dx.doi.org/10.1093/jxb/41.9.1167.

FARIA, S.M., FRANCO, A.A., JESUS, R.M., MENANDRO, M.S., BAITELLO, J.B., MUCCI, E.S.F., DOBEREINER, J. and SPRENT, J.I., 1984. New nodulating legume trees from south-east Brazil. The New Phytologist, vol. 98, no. 2, pp. 317-328. http:// dx.doi.org/10.1111/j.1469-8137.1984.tb02742.x.

FERREIRA, S.A.D.N. and SANTOS, L.A., 1993. Efeito da velocidade de secagem sobre a emergência e vigor de sementes de pupunha (Bactris gasipaes Kunth). Acta Amazonica, vol. 23, no. 1, pp. 3-8. http://dx.doi.org/10.1590/1809-43921993231008.

FONSECA, S.C.L. and FREIRE, H.B., 2003. Sementes recalcitrantes: problemas na pós-colheita. Bragantia, vol. 62, no. 2, pp. 297-303. http://dx.doi.org/10.1590/S0006-87052003000200016.

GARCIA, I.S., SOUZA, A., BARBEDO, C.J., DIETRICH, S.M.C. and FIGUEIREDO-RIBEIRO, R.C.L., 2006. Changes in soluble carbohydrates during storage of Caesalpinia echinata LAM. (Brazilwood) seeds, an endangered leguminous tree from the Brazilian Atlantic Forest. Brazilian Journal of Biology = Revista Brasileira de Biologia, vol. 66, no. 2B, pp. 739-745. http://dx.doi. org/10.1590/S1519-69842006000400018. PMid:16906306.

KAUTH, P.J. and BIBER, P.D., 2014. Moisture content, temperature, and relative humidity influence seed storage and subsequent survival and germination of Vallisneria americana seeds. Aquatic Botany, vol. 120, pp. 297-303. http://dx.doi. org/10.1016/j.aquabot.2014.09.009.

LIMA, H.C., 2015. [viewed 4 February 2019] Melanoxylon in Lista de Espécies da Flora do Brasil [online]. Jardim Botânico do Rio de Janeiro. Available from: http://floradobrasil.jbrj.gov. br/jabot/floradobrasil/FB28147.

LORENZI, H., 1992. Árvores brasileiras: manual de identificação e cultivo de plantas arbóreas nativas do Brasil. 2. ed. Nova Odessa: Editora Plantarum, $352 \mathrm{p}$.

MAGUIRE, J.D., 1962. Speed of germination aid in selection and evaluation for seedling emergence and vigor. Crop Science, vol. 2, no. 2, pp. 176-177. http://dx.doi.org/10.2135/cropsci196 2.0011183X000200020033x.

MARCOS FILHO, J., 2005. Fisiologia de sementes de plantas cultivadas. 1. ed. Piracicaba: Fealq. 495 p.

MCDONALD, M.D., 1999. Seed deterioration, physiology, repair and assessment. Seed Science and Technology, vol. 22, no. 3, pp. 531-539.

MENDONÇA, A.P., SILVA, L.M.M., SOUSA, F.C., SILVA, J.R. and ROSA, J.C., 2019. Modelagem matemática das curvas de 
secagem de sementes de duas espécies de andiroba. Engenharia na Agricultura, vol. 27, no. 4, pp. 293-303. http://dx.doi.org/10.13083/ reveng.v27i4.888.

NERY, F.C., PRUDENTE, D.O., ALVARENGA, A.A., PAIVA, R. and NERY, M.C., 2017. Storage of Calophyllum brasiliense Cambess. seeds. Brazilian Journal of Biology $=$ Revista Brasileira de Biologia, vol. 77, no. 3, pp. 431-436. http://dx.doi. org/10.1590/1519-6984.08115. PMid:27683804.

OLIVEIRA, A.K.M., ALVES, F.F. and FERNANDES, V., 2018b. Germinação de sementes de Vochysia divergens após armazenamento em três ambientes. Ciência Florestal, vol. 28, no. 2, pp. 525-531. http://dx.doi.org/10.5902/1980509832035.

OLIVEIRA, F.T.G., VITÓRIA, R.Z., POSSE, S.C.P., ARANTES, S.D., SCHMILDT, O., VIANA, A., MALIKOUSKI, R.G. and BARROS, B.L.A., 2018a. Qualidade fisiológica de sementes de aroeira em função das condições de armazenamento. Nucleus, vol. 15, no. 2, pp. 567-574. http://dx.doi.org/10.3738/1982.2278.2959.

OLIVEIRA, L.M., SILVA, E.O., BRUNO, R.L.A. and ALVES, E.U., 2011. Períodos e ambientes de secagem na qualidade de sementes de Genipa americana L. Semina: Ciências Agrárias, vol. 32, no. 2, pp. 495-502. http://dx.doi.org/10.5433/1679$0359.2011 \mathrm{v} 32 \mathrm{n} 2 \mathrm{p} 495$.

PARRELLA, N.N.L.D., 2011 [viewed 27 September 2019]. Armazenamento de sementes [online]. Belo Horizonte: EPAMIG. Available from: http://www.epamig.br/index.php?option=com docman\&task $=$ download\&gid $=1519$

PRITCHARD, H.W., HAYE, A.J., WRIGHT, W.J. and STEADMAN, K.J., 1995. A comparative study of seed viability in Inga species: desiccation tolerance in relation to the physical characteristics and chemical composition of the embryo. Seed Science and Technology, vol. 23, no. 1, pp. 77-89.

R DEVELOPMENT CORE TEAM, 2018. $R$ : a language and environment for statistical computing. Vienna: R Foundation for Statistical Computing.

RANDO, J.G., CARVALHO, D.A.S. and SILVA, T.S., 2019 [viewed 27 September 2019]. Melanoxylon. In: JARDIM BOTÂNICO DO
RIO DE JANEIRO - JBRJ. Flora do Brasil 2020 em construção [online]. Rio de Janeiro: JBRJ. Available from: http://floradobrasil. jbrj.gov.br/reflora/floradobrasil/FB28147

ROBERTS, E.H., 1973. Predicting the storage life of seeds. Seed Science and Technology, vol. 1, pp. 499-514.

SENA, L.H.M., MATOS, V.P., MEDEIROS, J.E., SANTOS, H.H.D., ROCHA, A.P. and FERREIRA, R.L.C., 2016. Storage of pitombeira seeds [Talisia esculenta (A. St. Hil) Radlk Sapindaceae] in different environments and packagings. Revista Árvore, vol. 40, no. 3, pp. 435-445. http://dx.doi.org/10.1590/010067622016000300007.

SILVA, A. and FERRAZ, I.D.K. 2015. Armazenamento de sementes. In: F.C.M. Pinã-Rodrigues, M.B. FIGLIOSA and A. SILVA, eds. Sementes Florestais: da ecologia à produção. Londrina: ABRATES, pp. 276-307.

SILVA, A., FIGLIOLIA, M.B. and AGUIAR, I., 1993. Secagem, extração e beneficiamento de sementes. In: I.B. AGUIAR, F.C.M. PINA RODRIGUES and M.B. FIGLIOLIA, eds. Sementes florestais tropicais. Brasília: ABRATES, pp. 303-331.

SILVA, D.G., CARVALHO, M.L.M.D., NERY, M.C., OLIVEIRA, L.M.D. and CALDEIRA, C.M., 2011. Alterações fisiológicas e bioquímicas durante o armazenamento de sementes de Tabebuia serratifolia. Cerne, vol. 17, no. 1, pp. 1-7. http://dx.doi.org/10.1590/ S0104-77602011000100001.

SILVA, M.S., CARVALHO, C.R., BORGES, E.E.L. and FARIA, J.M.R., 2014. Viability and cell cycle of Melanoxylon brauna seeds submitted to drying and imbibition. Journal of Seed Science, vol. 36, no. 2, pp. 162-167. http://dx.doi.org/10.1590/2317-1545v32n2913.

VILLELA, F. and PERES, W., 2004. Secagem e beneficiamento de sementes. In: A.G. FERREIRA and F. BORGHETTI, eds. Germinação: do básico ao aplicado. Porto Alegre: Artmed, pp. 265-281.

WALTERS, C., 1998. Understanding the mechanisms and kinetics of seed aging. Seed Science Research, vol. 8, no. 2, pp. 223-244. http://dx.doi.org/10.1017/S096025850000413X.v 